guard wires decrease the number of faults and protect the top conductor but apparently make the bottom conductor more liable to be struck. On the other hand, simultaneous double-line faults seem to occur more frequently when guard wires are used.

In spite of the severity of the storms that occur in the Rand, the operation of a single line of towers carrying two power lines has been successful. Since they started operation in April 1926 they have never been rendered unserviceable by a lightning fault. Most engineers would prefer to have two separate rows of towers several hundred metres apart each carrying three wires which form the edges of an equilateral prism. Some of the phenomena that would occur in this case would doubtless be similar to those observed by the authors.

\section{Atmospheric Pollution}

$\mathrm{T}$ HERE is an impression that American cities are smoke free. This is only true to a limited extent, and in some respects Americans are very tolerant. The smoke of an American railway engine must be seen to be believed, and Dr. Meller's broadcast talk on December 28, 1933 ("The Smoke Abatement Outlook". By H. B. Meller. The Mellon Institute, Pittsburgh), tells a tale of the evil and damage done by smoke, which reads very familiar. He makes the point that following water, sanitation and food comes naturally the need to improve the quality of our air supply. "Remember," he says, "the demand we are now hearing for a new deal in air is coming from those who are living in houses of the type to which we long have been accustomed. How much stronger will be the cry for effective abatement of smoke when we begin to promote construction of the new style dwellinghouse which seience has developed. Samples of such houses were enthusiastically viewed for the first time by the masses at the Century of Progress Exposition. Small houses they are, with flat roof surfaces devoted to play spaces and sun parlours ; all of them equipped for air conditioning ; every one constructed so that each room can be flooded with sunlight. In short, dwellings designed to make much fuller use of free and inexhaustible health-giving natural resourcespure air and unfiltered sunlight. Smoke challenges the use and enjoyment of houses of the new type. Excessive air pollution largely defeats the purposes of a roof playground and sun parlor. The sooner we realise these facts, the quicker we will take steps to bring smoke under adequate control."

Dr. Meller goes on to plead for withdrawing exemption from smoke abatement ordinances from domestic fires and due attention to atmospheric pollution in schemes of rehousing. Both pleas are also relevant in Great Britain. The traditional pitched roof was inevitable so long as available weatherproof materials could only be got in small pieces, but quite unnecessary now that modern methods and materials of construction enable the flat roof to be easily made. Flat roofs would greatly increase the effective area of cities, as a glance at maps will show, and that without extending the boundaries. Moreover, this roof area, the most remote from traffic and noise, will be increasingly prized as smoke is diminished. The realisation of all this may be expected to increase the call for cleaner atmosphere by many who are now indifferent--householders, property owners and civic authorities. Unfortunately it is just here where individual action is so ineffective, and full benefit can only be realised by the construction of whole estates without smoky appliances. What an opportunity is presented by our new housing schemes if only it could be grasped !

The report of the investigation on air pollution described by the Department of Scientific and Industrial Research (H.M. Stationery Office. 5s. net) shows that systematic recording is increasing and that improvement of atmospheric conditions continues. Pollution by motor exhausts has been examined this year, but systematic recording is not deemed necessary. The deposit of tar, compared with the average of the previous five years, was lower by 14 per cent and of total solids by 11 per cent. Deposition of sulphates has also diminished. The highest figure was recorded at Ravenscourt Park, London, and the lowest at Templenewsam Park in East Leeds. Westminster is one of the worst spots in the country for smoke haze, from which again Coventry is practically free. Coventry is a model city in this respect, whereas London compares unfavourably with many industrial towns.

The limited measurements available indicate that the loss of sunlight due to air pollution averages 20 per cent over the year and more than this in winter. Last year the reasons for the fine records for Coventry were given as being partly geographical and partly the extensive use of smokeless methods in domestic and industrial practice. The lesson of these records cannot be too widely published at the present time,

H. J. H.

\section{University and Educational Intelligence}

CAMBridge.-The General Board has given notice that Dr. C. G. Lamb will resign the readership in electrical engineering on September 30, but it is not intended to recommend the continuation of the readership.

R. D. Davies, of Gonville and Caius College, has been appointed University demonstrator in engineering.

At King's College, A. M. Turing has been elected to a Harold Fry studentship, K. C. Dixon to an additional Harold Fry studentship and J. W. S. Pringle to a Martin Thackeray studentship.

At Trinity College, Dr. L. Borinski has been elected to a research studentship and W. E. Bennett and D. P. R. Petrie have been elected to Dominion and Colonial exhibitions in physics.

A crNema museum, wherein should be housed films of outstanding artistic and scientific merit, is advocated in an article by Elma Dangerfield in a recent issue of Film Progress. The project is linked with the scheme of the Shakespeare Film Society formed under the chairmanship of Sir Frank Benson. The same issue of Film Progress contains a very informative article by Charles Brawn, which relates how during the past five years he has evolved a successful technique of exhibition of films in schools, and formulates a number of definite conclusions arrived at by the school staff as a result of five years' experience. It seems clear that films are playing an increasingly important part in schools. A glance at a recent issue of a school magazine (Stoic, April) shows that the cinema figures prominently in seven separate reports of extra-curricular activities, including those of a natural science society, a natural history society, a film society and a motion picture 